\title{
DIE INSPEKTEUR-GENERAAL IN DIE SUID- AFRIKAANSE WEERMAG 1912 - 1983
}

\section{Kmdt C J Nöthling*}

This historical review of the role of the Inspector General in the South African Defence Force since 1912 is by the author's own admission, not an unbroken saga of continuous events. This is clearly demonstrated by the fact that the post of Inspector General had been abolished (and created) on several occasions. In view of this it is perhaps understandable that from a diachronical viewpoint, opinions on the role and status of the Inspector General will differ. The aim of this article is to review the aspect of semantics within a historical framework and the author bases his arguments on the premise that the post of the Inspector General is to a large extent influenced by evolutionary change within the organizational framework. It is also claimed that the history of the Inspector General in the South African Defence Force should not be viewed in isolation and in this regard note is taken of the role played by the Inspector General in the forces of Britain (origins) and the United States (currently). The move away from the traditional centralized Inspector General towards a decentralized system which makes provision for Inspectors General allocated to the respective arms of service, is seen as a normal development in the evolutionary process which will contribute towards improved efficiency.

\section{Inleiding}

Die herinstelling van die pos Inspekteur-generaal SAW, op 1 Desember 1981 ,' was in 'n sekere sin die voortsetting van ' $n$ heel besondere kroniek in die geskiedenis van die Suid-Afrikaanse Weermag. Terselfdertyd is ook ' $n$ nuwe wending en betekenis verleen aan dié posbenaming want sover dit sy gesagsposisie, rol en funksie betref, verskil die huidige amp van die Inspekteur-generaal aansienlik van dié van die eerste Inspekteur-generaal (Staande Mag) wat op 1 Julie 1912 diens aanvaar het. ${ }^{2}$ In die afgelope 70 jaar was die geskiedenis van die Inspekteur-generaal in die Suid-Afrikaanse militêre bestel allesbehalwe deurlopend - dié pos, wat na gelang van omstandighede voortdurend onderhewig was aan organisatoriese veranderinge, is by verskillende geleenthede afgeskaf. Die afgebroke aard van sy geskiedenis blyk onder meer uit die feit dat die Unieverdedigingsmag vanaf 1921 tot 1953 nie 'n Inspekteur-generaal op sy diensstaat gehad het nie.

In die lig hiervan is dit derhalwe begryplik dat vanuit ' $n$ diakroniese gesigspunt daar nooit werklik sprake was van absolute eenstemmigheid oor die gesag en funksies van die Inspekteur-generaal nie. Insgelyks het wanopvattinge oor dié amp in militêre kringe posgevat wat die werklike beeld van die Inspekteur-generaal verder vertroebel het. Die doel van hierdie artikel is enersyds om die semantiese problematiek rakende die Inspekteur-generaal (as begrip) indringend te ondersoek en andersyds om sy ge- skiedenis in die geskiedenis van die Suid-Afrikaanse Weermag sinvol aan te bied. Verder moet gelet word op die feit dat die geskiedenis van die Inspekteur-generaal nie in isolasie verloop het nie; buitelandse beïnvloeding het selfs 'n deurslaggewende rol gespeel en derhalwe word in hierdie oorsig ook kennis geneem van dié aspek.

\section{Oorsprong}

Sover vasgestel kan word, kom die eerste verwysing na die term Inspekteur-generaal voor in die "Articles of War" wat in 1629 deur die Britse vors Karel 1 uitgevaardig is. Die koninklike dekreet het soos volg gelui:

'The Inspector General must have a horse allowed to him and some soldiers to attend him and all the rest commanded to obey and assist, or else the Service will suffer; for he is but one man and must correct many and therefore he cannot be beloved. And he must be riding from one Garrison to another to see that soldiers do not outrage nor scath the country. ${ }^{\prime 3}$

Kronieke oor die geskiedenis van die Britse Leër verleen egter nie veel prominensie aan die status en rol van die Inspekteur-generaal nie. Enkele voorbeelde van dié term se gebruik toon nietemin dat Inspekteurs-generaal toegewys is aan die onderskeie gevegsindelings soos byvoorbeeld die infanterie. Die volgende verwysings kom in die uitgebreide Oxford English Dictionary voor: 
'1702 Lond. Gaz. No. 3841/3 Monsieur Puissegure, Inspector-General of their Foot. 1813 Wellington Lett. 4 Oct. in Gurw. Desp. XI. 159 The Inspector General of the infantry fell from his horse. 1859 Musketry Instr. 98 The Inspector General of Musketry, being held responsible that the rifle training is conducted efficiently and according to regulation. ${ }^{4}$

Die skep van 'n oorhoofse pos wat die Britse Leër in sy geheel sou bedien, is klaarblyklik eers ná die beëindiging van die Tweede Vryheidsoorlog in 1902 oorweeg. In 1904 het 'n komitee van ondersoek insake die reorganisasie van die Leër in sy eerste verslag aanbeveel dat die pos van Inspekteur-generaal geskep word. Die betrokke komitee het verder voorsien dat die funksies van die Inspekteur-generaal sou neerkom op 'those of review and report upon the practical results of the policy of the Army Council within the financial limits laid down by the Cabinet. ${ }^{15}$

Die gesagstatus van die voorgestelde pos van Inspekteur-generaal met betrekking tot die pasgestigte Army Council dien kortliks vermeld te word. In hierdie verband blyk sy relatiewe status uit die feit dat hy nie saam met die vier militêre lede van die Britse Opperbevel in die Raad gedien het nie. ${ }^{6}$ Desondanks was die uittredende opperbevelhebber van die Britse Leër, veldm lord F.S. Roberts, die eerste offisier wat vir dié pos genomineer is. ${ }^{7}$ maar toe hy dié pos aangebied is, het die Britse Koning teenoor veldm lord Roberts laat blyk dat ' $n$ voormalige opperbevelhebber van die Britse Leër nouliks 'n Inspekteurgeneraal kon wees! Roberts, wat in een stadium op die aandrang van lord Balfour dit wel oorweeg het, het die aanbod van die hand gewys en 'n aanstelling in die Verdedigingskomitee aanvaar. Hierop is die hertog van Connaught (wat die eerste Unieparlement in 1910 sou open) as Inspekteur-generaal van die Britse Leër aangewys.

\section{Die Inspekteur-generaal in Suid-Afrika}

Die herkoms van dié posbenaming in Suid-Afrika hou grootliks verband met die instelling van verantwoordelike bestuur in Transvaal enkele jare voor Uniewording. $\mathrm{Na}$ aanleiding hiervan is die opperbevel van die Transvaal Volunteers na die koloniale sekretaris oorgedra en in ooreenstemming hiermee is die posbenaming 'Commandant of the Transvaal Volunteers' in Julie 1908 na 'Inspector of the Transvaal Volunteers' gewysig. ${ }^{8}$ Kol Percy Scot Beves is op 1 Julie 1908 in hierdie nuwe pos aangestel en hy het dit beklee tot en met die ontbinding van die Transvaal Volunteers in 1913. Ná die totstandkoming van die Unieverdedigingsmag is kol Beves aangestel as Kommandant van die Kadette.

Wat die pos van 'Inspector of the Transvaal Volunteers' betref, is dit klaarblyklik geskep om die bevelvoerder van roetine-administrasie vry te stel sodat hy meer aandag kon gee aan beleidsake, toesig en inspeksie. Hy het bevel gevoer oor drie berede korpse met ' $n$ goedgekeurde sterkte van 3575 man.

Tydens die Durbanse konferensie in Oktober 1908 is samesprekings op interkoloniale vlak gevoer oor die kwessie van gelykvormigheid in die onderskeie koloniale magte. Sekere aanbevelinge is gedoen na aanleiding waarvan die Inspekteur van die Transvaal Volunteers opdrag gekry het om twee skemas op te stel wat op binnelandse beveiliging gemik sou wees. Hoewel dié skemas opgestel is, is dit nooit in werking gestel nie. ${ }^{9}$

Die Kadetorganisasie in Transvaal was ook onder die Inspekteur se beheer. Hy het dan ook ' $n$ belangrike rol gespeel in die reorganisasie van die kadetkorpse in Julie $1908 .{ }^{10}$

Met die totstandkoming van die Unieverdedigingsmag in Julie 1912, is die pos van Inspekteur van Vrywilligers (Transvaal) afgeskaf." Insgelyks is drie onafhanklike bevelvoerings ingestel, onder meer dié van Inspekteur-generaal Staande Mag. Brig genl H.T. Lukin (KCB, CMG, DSO), 'n gebore Brit en oorlogsveteraan wat onder andere aan die Tweede Vryheidsoorlog deelgeneem het, was die eerste posbekleër. Onderhewig aan die voorskrifte van die Minister van Verdediging, was hy verantwoordelik vir die organisasie, bevelvoering, opleiding, doeltreffendheid en dissipline van die Zuid-Afrikaansche Bereden Schutters (ZABS) wat die Staande Mag sou uitmaak. Die Inspekteur-generaal was ook verantwoordelik vir die behoorlike en doeltreffende lewering van polisiedienste deur die ZABS in sekere gebiede soos in die Verdedigingswet voorgeskryf. Verder moes hy ook kandidate vir offisiersaanstelling of bevordering in die ZABS selekteer en evalueer.

Brig genl Lukin het die eerste jaar van sy dienstermyn (1 Julie 1912 - 20 Junie 1913) grootliks gewy aan die voorbereidende werk ten opsigte van die ZABS se organisasie. ${ }^{12}$ Sy oorhoofse take was onder meer die bepaling van die ge- 
bied waarin kontrole uitgeoefen sou word, die keuring van offisiere en die tref van reëlings met betrekking tot werwing. Mannekragbeplanning moes ook gedoen word ten einde die vereiste magspeile te bepaal. Wat die uitvoer van inspeksies betref, het die Inspekteur-generaal in die eerste verslagjaar geen uitgebreide inspeksies onderneem nie en slegs in Noord-Transvaal en by die drie regimentshoofkwartiere kon besoeke afgelê word. ${ }^{13}$

In hierdie tydperk het binnelandse onruste veroorsaak dat Lukin 'n groot deel van sy tyd moes bestee aan die mobilisasie van ongeveer 700 soldate. Verder moes patrollies uitgestuur word om onderlinge stamgevegte te onderdruk.

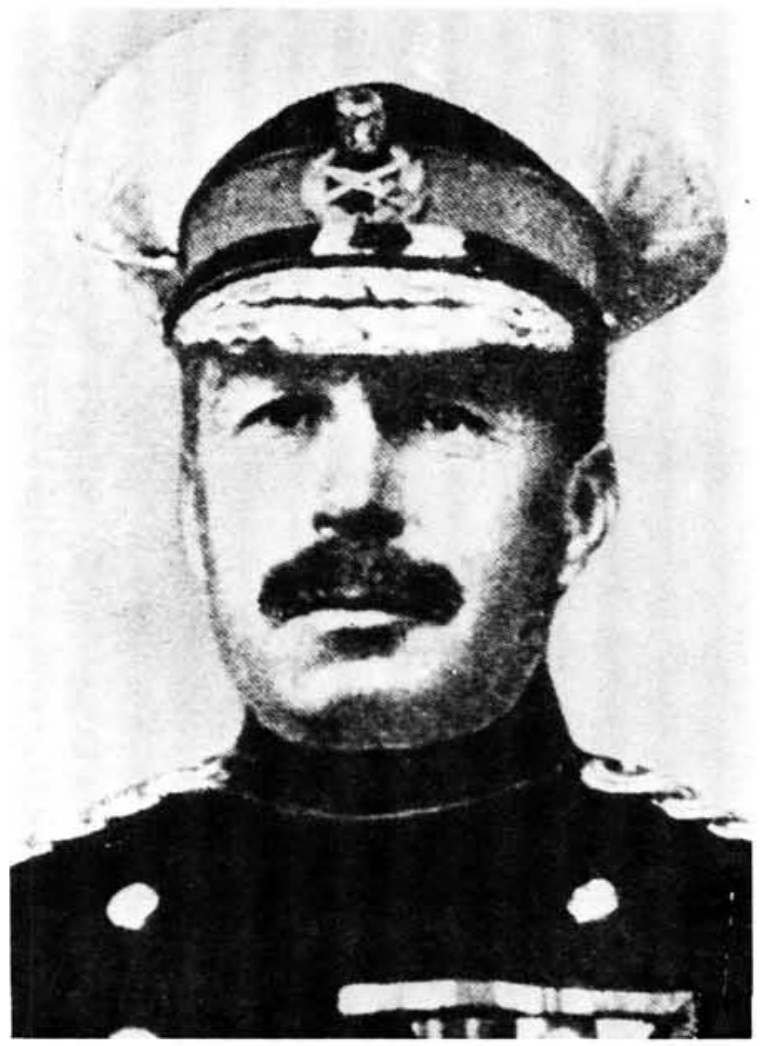

Genl maj Sir H.T. Lukin (1860 - 1925)

In 1914 het die Eerste Wêreldoorlog uitgebreek. Brig genl Lukin se heeltydse betrokkenheid in die veldtog in Suidwes-Afrika en sy latere aanstelling as Bevelvoerder SA Brigade ${ }^{14}$ het meegebring dat hy sy pligte as Inspekteur-generaal beswaarlik kon nakom - gevolglik het kol C.A.L. Berrange (CMG, DSO) hom op 21 Julie 1915 in 'n waarnemende hoedanigheid opgevolg. ${ }^{15}$ Maar klaarblyklik is kol Berrange se aanstelling ook deur krygsverpligtinge geraak, want op 14 Desember 1915 moes hy dié pos ontruim. Op die volgende dag is hy tot brigadier-generaal bevorder en as brigadebevelvoerder van 3 SA Infanteriebrigade na die front in Oos-Afrika gestuur. Op 12 Julie 1917 het hy egter weer diens as waarnemende Inspekteur-generaal aanvaar en vanaf 1 Maart 1919 het hy ook bevel gevoer oor alle Unie- en Imperiale magte in die militêre gebied Robertshoogte. Laasgenoemde aanstelling het op 15 Januarie 1920 verval, dog brig genl Berrange het as waarnemende Inspekteurgeneraal aangebly totdat dié pos op $31 \mathrm{De}$ sember 1921 afgeskaf is.

Met die sluiting van die kantoor van die Inspekteur-generaal, is sy werksaamhede na die afdeling van die Adjudant-generaal oorgedra. Hierdie stap was ' $n$ uitvloeisel van die grootskaalse reorganisasie wat in 1920 in die Unieverdedigingsmag plaasgevind het.

Meer as 31 jaar sou verloop voordat die pos van Inspekteur-generaal weer ingestel is. Op $1 \mathrm{Mei}$ 1953 het genl maj H.B. Klopper (DSO) diens aanvaar as Inspekteur-generaal, Unieverdedigingsmag. Hy was aan die Hoof van die Generale Staf verantwoordelik vir die uitvoering van veral vier hooftake, $\mathrm{nl}$ die inspeksie van alle militêre inrigtings, eenhede, opleidingsentra en opbergingsplekke; die gee van leiding ten opsigte van opleiding en maneuvers; mobilisasie en skakeling met buitelandse militêre verteenwoordigers.

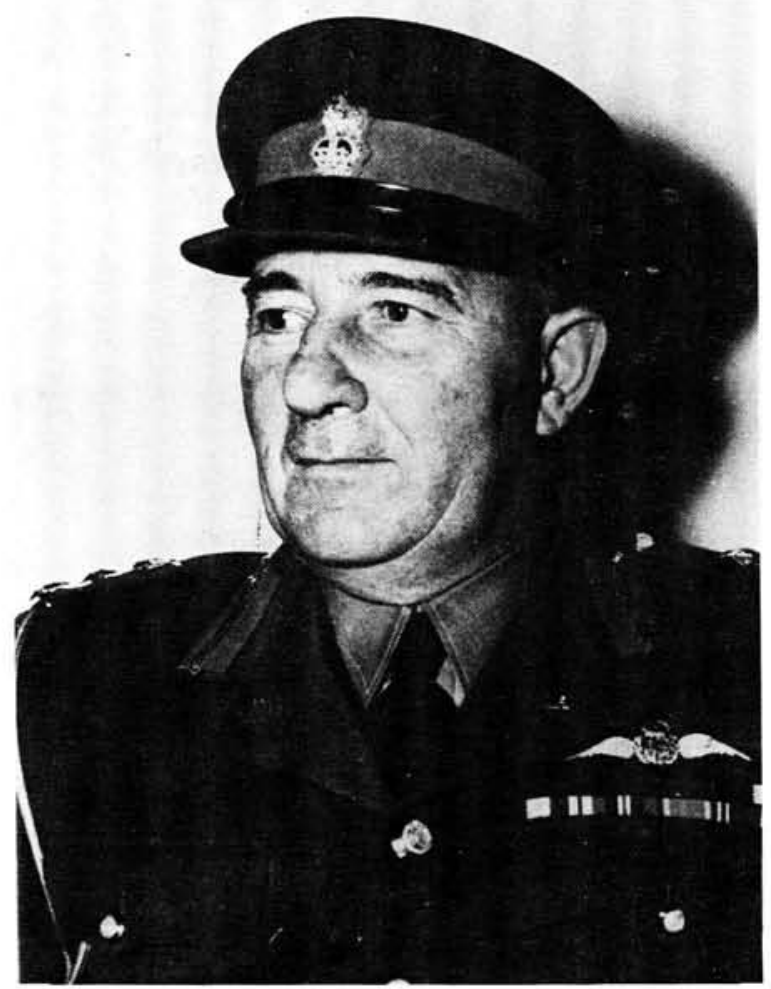

Kmdt genl H.B. Klopper (1902 - 1978) 
Wat die inspeksiefunksie betref, moes die Inspekteur-generaal verskeie aangeleentehede ondersoek, onder meer die peil van bekwaamheid, doeltreffendheid en dissipline. Inspeksies moes ook gedoen word oor die uitvoer van voorgeskrewe beleid, personeelsake (byvoorbeeld personeelsterktes en uitrustingtabelle), beveiliging, welsyn, huisvesting en administratiewe dienste.

Sy taak met betrekking tot opleiding en maneuvers het hoofsaaklik neergekom op die koördinering van gesamentlike opleiding en die gemeenskaplike aanwending van wapens en vervoermiddele. Wat mobilisasie betref, was hy verantwoordelik vir die koördinering van mobilisasiebeleid en die daarstelling van spesiale skemas en voorsorgmaatreëls vir die bekamping van binnelandse onluste.

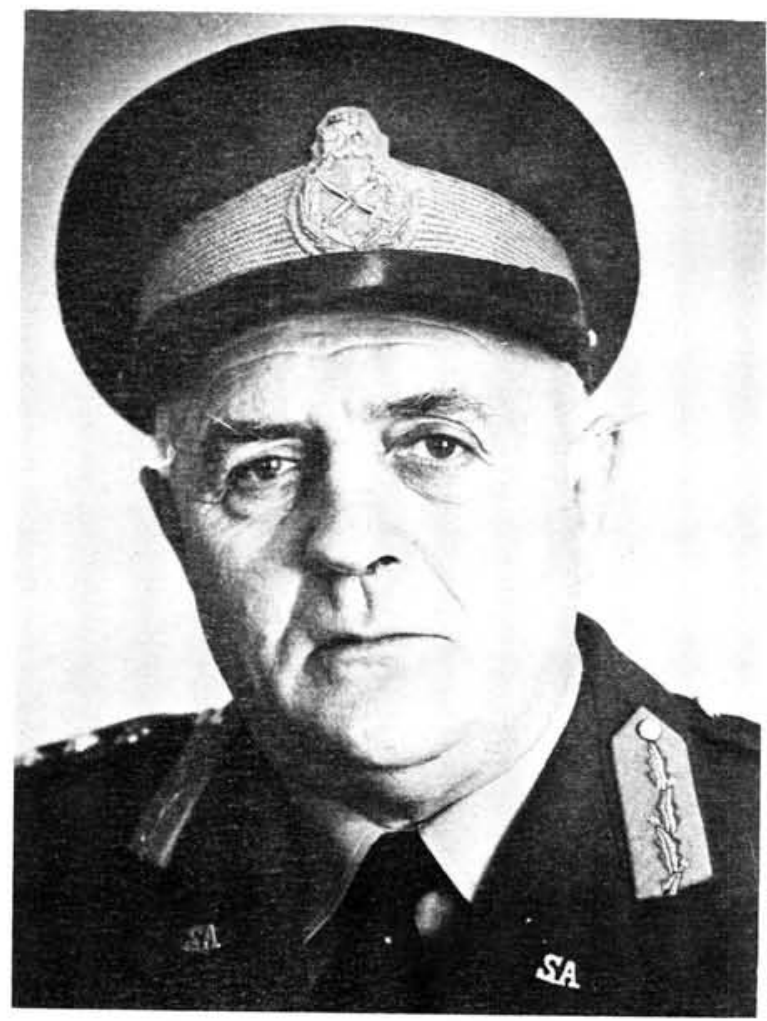

Kmdt genl S.A. Melville (1904 - 1977)

Genl maj Klopper het op 23 September 1956 kommandant-generaal van die Unieverdedigingsmag geword en genl maj S.A. Melville (SSA, OBE) het hom op dieselfde dag as Inspekteur-generaal opgevolg. Genl maj Melville sowel as sy opvolger, genl maj P.H. Grobbelaar (SSA, DSO), het later in die voetspore van kmdt genl Klopper gevolg: toe eersgenoemde op 25 September 1958 kommandant-generaal geword het, is hy deur genl maj Grobbelaar as Inspekteurgeneraal opgevolg. Trouens, hierdie tradisie is selfs verder voortgesit deur genl maj R.C. Hiemstra (SSA, SM) wat op 1 November 1959 Inspekteur-generaal geword het. Laasgenoemde het op 1 Oktober 1965 kommandantgeneraal geword toe kmdt genl P.H. Grobbelaar uitgetree het.

In die vyftigerjare het die behoefte aan 'n militêre inspektoraat, wat in breë trekke dieselfde doel sou dien as die Staatsdiensinspektoraat (wat ander Staatsdepartemente bedien het), algaande ontwikkel. Daar is gevoel dat inspekteurs noodsaaklik was om te verseker dat die verskillende weermagsdele ' $n$ hoë peil van doeltreffendheid ten opsigte van organisasie en werksmetodes handhaaf.

$\mathrm{Na}$ aanleiding hiervan is ' $\mathrm{n}$ Militêre Inspektoraat op 15 Januarie 1959 onder die beheer van die Inspekteur-generaal ingestel. Dit het bestaan uit die Inspekteur-generaal (voorsitter), die Adjunkinspekteur-generaal en sewe inspekteurs van wie elkeen ' $n$ afgebakende veld van ondersoek gehad het. ${ }^{16}$

Die Departementele Inspekteur, wat ook as skakellid van die Inspektoraat opgetree het, was belas met die inspeksie van dienste soos vervoer, behuising, akkommodasie en menasies. Die ses Militêre Inspekteurs se taakverdeling was soos volg:

- Een Militêre Inspekteur is belas met die inspeksie van rapportering oor militêre opleiding (tegnies en vakopleiding uitgesluit) met inbegrip van die Militêre Akademie, gimnasiums, die Mobiele Wag, kolleges en ander opleidingsinrigtings, kampe, bivakke en aspekte van wapens en uitrusting.

- Een Militêre Inspekteur was vir die inspeksie van administratiewe militêre dienste, organisasie en werksmetodes asook mannekrag verantwoordelik.

- Een Militêre Inspekteur sou inspeksies oor 'operatiewe' militêre dienste uitvoer.

- Twee Militêre Inspekteurs was verantwoordelik vir die inspeksie van militêre voorrade. insluitende klerasie.

- Een Militêre Inspekteur is met tegniese en vakopleiding belas.

Die primêre funksie van die Inspektoraat was om doeltreffendheid in die Suid-Afrikaanse Weermag te bevorder en om finansiële besparing in die hand te werk. In hierdie verband moes 'n wye 
spektrum van sake ondersoek word, onder meer organisasie; prosedures en metodes; toesighouding; die vereenvoudiging en koördinering van werkstake; die herindeling van funksies en poste; die aanwending van kantore, menasies en bergruimte; en dissipline en moreel.

Die Inspektoraat het geen uitvoerende gesag gehad nie en moes slegs in ' $n$ adviserende hoedanigheid met die betrokke afdelings en instansies in die Suid-Afrikaanse Weermag skakel. Verslae oor ondersoeke is aan die Kommandantgeneraal en die Sekretaris van Verdediging voorgelê wat saam die bevindings en aanbevelings oorweeg het.

Op 1 November 1959 is mnr C.W.C. van Heerden aangestel as Sekretaris van die Beplanningsraad (SAW), die Inspektoraat (SAW) en die Suid-Afrikaanse Lugmag se Beplanningskomitee. Aangesien sekere funksies van die Militêre Inspektoraat na die Beplanningskomitee oorgeplaas is, moes die aanstelling van inspekteurs so gewysig word dat hulle nie meer slegs vir ' $n$ spesifiek weermagsdeel verantwoordelik sou wees nie. Die inspekteurs sou dus in die toekoms gebruik word om enige ondersoek of inspeksie binne die raamwerk van die Militêre Inspektoraat se funksies te onderneem.

Die oordrag van funksies na die Beplanningskomitee is op 23 November 1959 verder gevoer toe die Kommandant-generaal die Inspekteur-generaal verwittig het dat die Beplanningskomitee voortaan self alle voltooide inspeksieverslae sou hanteer. Opvolgaksies in verband met sodanige verslae sou in samewerking met die Sekretaris van Verdediging (en indien nodig, die staf- en seksiehoofde) gedoen word. Beleidsake sou egter regstreeks na die Kommandant-generaal verwys word.

Die pos van Inspekteur-generaal is ná minder as agt jaar op 31 Desember 1960 vir die tweede maal afgeskaf. Dit is vervang deur die posbenaming Direkteur van Beplanning en Operasies op die staf van die Kommandant-generaal. Die Militêre Inspektoraat is terselfdertyd op 1 Januarie 1961 na die afdeling van die Adjudant-generaal oorgeplaas. In die daaropvolgende dekade het hierdie inspektoraat verskeie naams- en organisatoriese veranderinge ondergaan. ${ }^{17}$

Die snelle uitbreiding van die Suid-Afrikaanse Weermag in die sestigerjare het meegebring dat in 1970 opnuut besin moes word oor nuwe organisatoriese aanpassings wat die bestaande be- vel- en beheerstruktuur sou raak. Die omvattende ondersoek wat hieruit voortgespruit het, het onder meer getoon dat inspeksiedienste dringend aandag moes geniet. ${ }^{18}$ ' $n$ Aanbeveling in hierdie verband het dan ook meegebring dat die Verdediginginspektoraat onder die beheer van die Direkteur-generaal Bestuurstelsels geplaas is. ${ }^{19}$ Die eerste posbekleër van laasgenoemde afdeling was genl maj L.H. Groenewald, 'n stigterslid van die gewese Militêre Inspektoraat (vide verwysing 16$).^{20}$ Die nuwe Verdedigingsinspektoraat het bestaan uit 22 lede van die Suid-Afrikaanse Weermag wat in Organisasie en Metode (O en $M$ ) opgelei is. Hiervan het 10 offisiere die Leër verteenwoordig terwyl die Lugmag en die Vloot deur onderskeidelik 10 en 8 offisiere verteenwoordig is.

Die sogenaamde 'Leërgroep' het, benewens hul gemeenskaplike O- en M-kwalifikasie, ook die onderskeie korpse verteenwoordig. Onder die Lugmagoffisiere was daar tegnici, vlieëniers, uitrustingsoffisiere, administratiewe offisiere en 'n lugverkeersleier. In die 'Vlootgroep' het offisiere met wye ondervinding sowel aan wal as ter see gedien. Brig L.L. Gordon (DFC) vandie Suid-Afrikaanse Lugmag het as Hoofinspekteur van die Verdedigingsinspektoraat gedien. ${ }^{21}$

Die doel van die Verdedigingsinspektoraat was kortliks om doeltreffendheid in die Suid-Afrikaanse Weermag te bevorder. As sodanig het dit op vele terreine beweeg en onder meer is knelpunte soos vormbeheer en die voertuiglogboekstelsel ondersoek. $\mathrm{Na}$ aanleiding van dié ondersoekprojekte is die administratiewe gebruik van bykans 3000 geregistreerde vorms na ongeveer 800 verminder terwyl 'n nuwe ritmagtiging- en vervoerbeheerstelsel in gebruik geneem is. Laasgenoemde stelsel het konserwatief bereken ' $n$ jaarlikse besparing van R50000 teweeggebring.

Die omvang en aard van die projekte wat deur die Verdedigingsinspektoraat aangepak is, was velerlei en uiteenlopend en kan uiteraard nie in die bestek van hierdie oorsig volledig behandel word nie. Enkele projekte wat vermelding verdien, was die outomatisering van Burgermagsoldy, die vereenvoudiging van dienspligoproepmetodes en die opknapping van werkswinkelprosedures. 'n Ondersoek na die Vloot se bevoorradingsprosedures is ook gedoen. Op die gebied van lugverdediging het 'n ondersoek deur ' $n$ lid van die Verdedigingsinspektoraat ' $n$ tydverbetering in die opstel van mobiele radarstasies in die hand gewerk. Voorts het die 
Verdedigingsinspektoraat saam met die Direktoraat Elektroniese Dataverwerking ook gewerk aan die rekenarisering van voorrade in die SuidAfrikaanse Weermag. ${ }^{22}$

Inmiddels is ' $\mathrm{n}$ pos $\mathrm{nl}$ Direkteur-generaal vir Leëropleiding en Inspekteur-generaal ook op 1 Junie 1970 op die diensstaat van die Hoof van die Leër ingestel. Genl maj J.J. Stapelberg (SM) is in dié pos aangestel en hy was aan die Hoof van die Leër verantwoordelik vir die oorhoofse beheer oor die opleiding van alle lede van die Leër. ${ }^{23}$ Hierdie funksie het in hoofsaak neergekom op die opleiding van personeel (alle leërkorpse), die evaluering van nuwe taktiese en tegniese ontwikkelinge en navorsing in korpsverband met betrekking tot nuwe leerstellinge. Daarbenewens is ' $n$ aantal bykomende take aan hom opgedra, onder meer die uitreiking van opleidingsprogramme en leerplanne; raadgewing in verband met die toewysing van eenhede/elemente vir operasionele take; inspeksie van en verslaggewing oor die slagvaardigheid asook die organisatoriese en funksionele doeltreffendheid van eenhede; en die opstel en uitreiking van pligstate aan die Direkteur Opleiding en korpsdirekteure.

Ofskoon die Direkteur-generaal vir Leëropleiding en Inspekteur-generaal uitsluitlik binne opleidingsverband opgetree het, was dit nietemin die eerste maal dat ' $n$ weermagsdeel oor sy eie inspekteur-generaal beskik het.

Op 1 Julie 1971 is die pos Inspekteur-generaal SAW weer eens op die Kommandant-generaal se diensstaat geskep. Genl maj F.W. Loots (SSA, $\mathrm{SM}$ ) is op dieselfde datum in dié pos aangestel.

Vanweë die noodsaaklikheid van doeltreffendheidsevaluering in die Suid-Afrikaanse Weermag, het die Bevel- en beheerkomitee (SAW) in 1973 aanbeveel dat die Hoof van die Suid-Afrikaaṇse Weermag en die drie weermagsdeelhoofde elkeen oor 'n eie Inspekteur-generaal moes beskik. Die onus vir die uitvoering van interne doeltreffendheid sou steeds by individuele bevelvoerders en hoofde van stafafdelings berus en die Inspekteur-generaal sou slegs verantwoordelik wees vir die oorhoofse bepaling van tekortkominge. Hierdie tekortkominge sou betrekking hê op die slagvaardigheid van die Suid-Afrikaanse Weermag in die algemeen en die onderskeie weermagsdele in die besonder. In die verslag, wat op 26 Junie 1973 vrygestel is, is die volgende aanbevelings vervat:
- Dat die inspeksiefunksies van die toenmalige Bevelvoerende Generaal Gesamentlike Gevegsmagte en die bevelvoerder Maritieme Verdediging aan die voorgenome Weermagsinspektoraat toegewys word.

- Dat ' $n$ Weermagsinspektoraat in die lewe geroep word 'om die operasionele doeltreffendheid van die Suid-Afrikaanse Weermag te evalueer.'

- Dat die Inspekteur-generaal SAW toevertrou word met die oorhoofse bepaling van tekortkominge ten opsigte van die Suid-Afrikaanse Weermag se operasionele doeltreffendheid en tweedens, met die verslaggewing daaromtrent aan die Hoof van die Suid-Afrikaanse Weermag.

- Dat op weermagsdeelvlak voorsiening gemaak word vir afsonderlike inspektorate, elkeen onder ' $n$ Inspekteur-generaal, met soortgelyke doelstellings as die Inspekteur-generaal SAW, dog elkeen tot sy eie weermagsdeel beperk.

In opvolging van hierdie aanbevelings is sleutelposte vir die Weermagsinspektoraat geskep wat op 1 Julie 1973 ingestel is. Op dié datum het die uittredende Hoof van die Leër, It genl W.P. Louw (SSA, SM) diens aanvaar as Inspekteur-generaal SAW. Hy het dié pos beklee tot kort voor sy uittrede op 31 Maart $1975 .{ }^{24}$

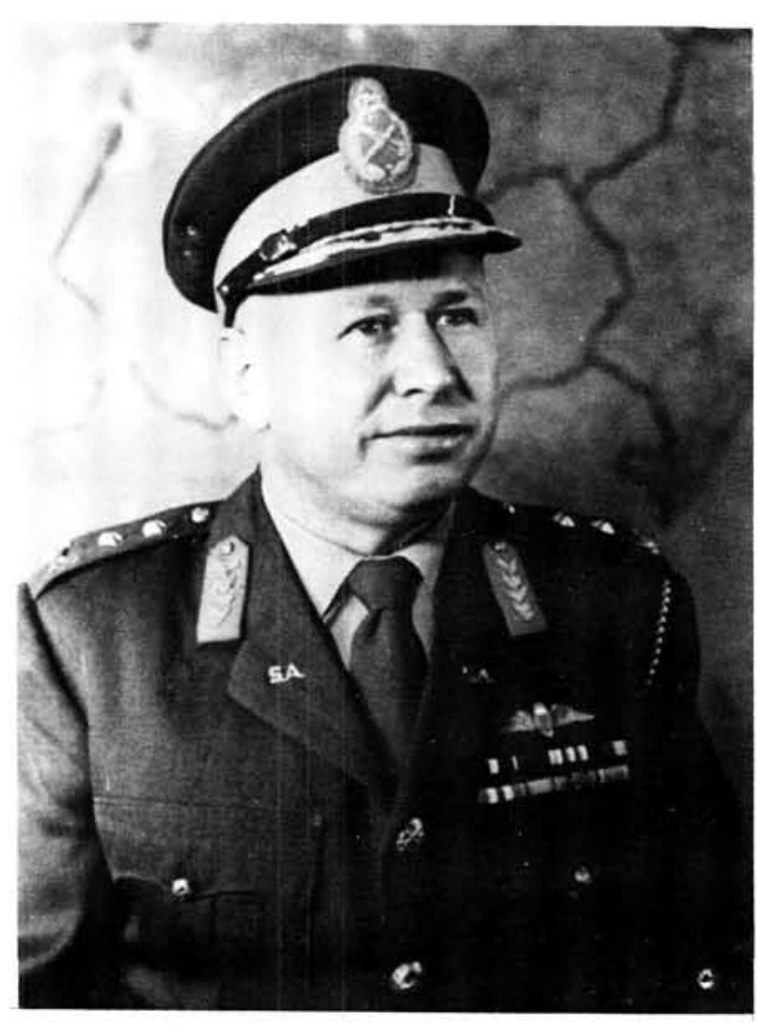

Lt genI W.P. Louw (1920 - 1980) 
Op daardie tydstip het die Leërinspektoraat alreeds bestaan. As gevolg van die herorganisasie van die Lugmaghoofkwartier, sou stappe in die afsienbare toekoms gedoen word om 'n Lugmaginspektoraat daar te stel. Inmiddels is ook aandag gegee aan die skep van 'n Vlootinspektoraat.

Hoewel die nuwe bedeling reeds op 1 Julie 1973 in werking getree het, sou dit spoedig blyk dat die evaluering van doeltreffendheid op ' $n$ effektiewer wyse deur die destydse Hoof van Staf se afdeling gedoen kon word. Wat die Inspekteursgeneraal van die weermagsdele betref, is tot die slotsom gekom dat spesifieke aspekte van slagvaardigheid en doeltreffendheid wel op weermagsdeelvlak ondersoek moes word en dat losstaande inspektorate in dié opsig die aangewese alternatief gebied het.

Die strydvraag $\mathrm{nl}$ oor waar die formele evaluering van operasionele doeltreffendheid op hoofkwartiervlak (SAW) eintlik tuisgehoort het, is met die Hoof van Staf, sy Direkteur-generaal Operasies en die Direkteur Evaluasie van die Weermaginspektoraat bespreek. Ná aanleiding hiervan is die volgende aanbevelings gedoen in ' $n$ verslag wat op 3 Julie 1974 uitgebring is:

- Dat die SA Weermagsinspektoraat / Inspekteur-generaal SAW afgeskaf word.

- Dat sekere poste vir die Weermagsinspektoraat goedgekeur is, na die Direktoraat Evaluasie en Doktrine van die Direkteur-generaal Operasies oorgedra word.

- Dat die bestaande aanbevelings ten opsigte van die beoogde daarstelling en ontwikkeling van die weermagsdele se inspektorate onveranderd bly.

Hierdie aanbevelings is op 19 Augustus 1974 deur die Minister van Verdediging goedgekeur en die SA Weermagsinspektoraat / Inspekteurgeneraal SAW se pos is op 1 Januarie 1975 ontbind. Sy funksies is na die Direkteur-generaal Operasies oorgedra en daarmee is nog ' $n$ fase in die geskiedenis van die Inspekteur-generaal afgesluit.

Hoewel die daarstelling van inspektorate vir die onderskeie weermagsdele goedgekeur is, kon daar aanvanklik min vordering in hierdie verband gemaak word. In 'n verslag wat op 19 Augustus 1977 deur die Direkteur Organisasiestudies vrygestel is, word onder meer vermeld dat die ses offisiersposte wat van die ontbinde Weermagsinspektoraat na die Direktoraat Evaluasie en Dok- trine oorgedra is, haas geen bydrae tot die beoogde evalueringsfunksies op verdedigingstafvlak gelewer het nie. Voorts is gewys op die feit dat die Direkteur van Evaluasie en Doktrine met veelvuldige take belas is waarvan geen enigsins verband met ò evaluering ò doktrine gehou het nie.

Die waarde en betekenis van hierdie verslag was egter daarin geleë dat dit ' $n$ aantal ingrypende aanbevelings bevat het en waarvan die herinstelling van ' $n$ Inspekteur-generaal SAW, sekerlik die belangrikste was. ${ }^{25}$ Hierbenewens is die voorgestelde afbakening van funksies vir die Inspekteur-generaal SAW en die Inspekteursgeneraal van die onderskeie weermagsdele duideliker omskryf. Een kardinale aanbeveling, nl dat die Inspekteur-generaal op weermagsdeelvlak regstreeks aan sy weermagsdeelhoof verantwoordelik moes wees, is later aanvaar.

Hierdie verslag is opgevolg deur ' $n$ verdere ondersoek en in Junie 1980 is pertinent aanbeveel dat die wenslikheid daarvan om ' $n$ inspektoraat (en dus ' $n$ pos Inspekteur-generaal SAW) op die vlak van Hoof van die Suid-Afrikaanse Weermag te skep, nogmaals oorweeg word. ${ }^{26}$ Dit is gedoen en op 1 Desember 1981 het genl maj H.D. Viljoen (SD) diens aanvaar as Inspekteur-generaal SAW. ${ }^{27}$

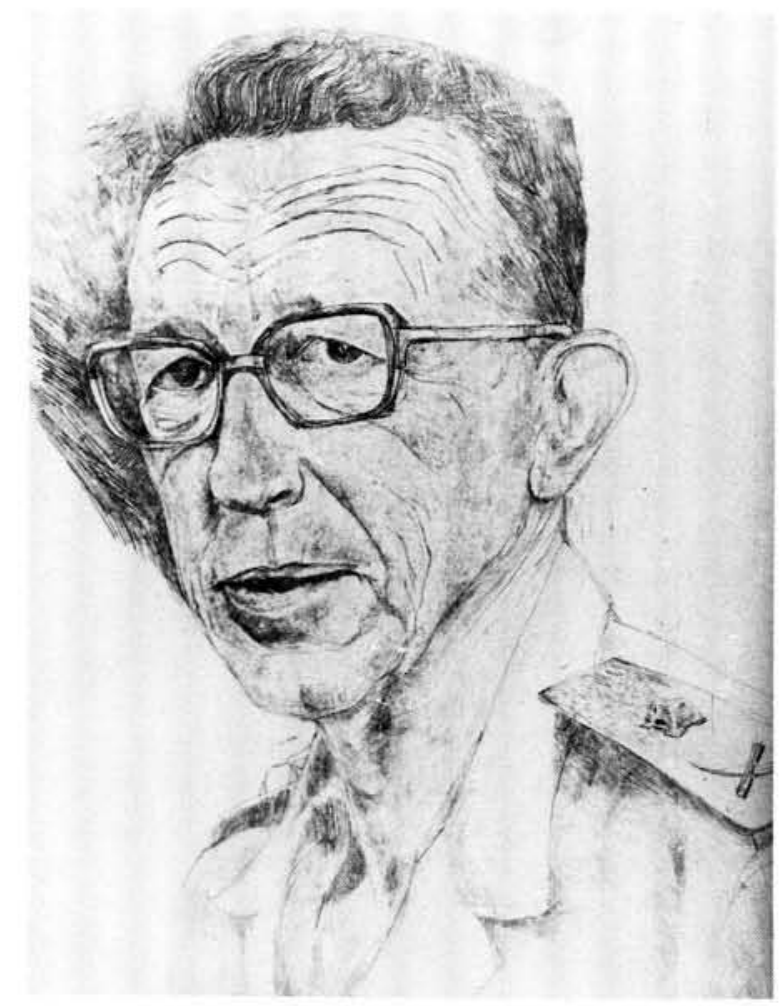

GenI maj H.D. Viljoen, huidige Inspekteur-generaal, SAW 
Die funksies van die Inspekteur-generaal SAW is om namens die Hoof van die Suid-Afrikaanse Weermag metodes/stelsels te ontwikkel ten einde die volgende aspekte op die hoogste vlak effektief te monitor: algemene administrasie; mannekragbenutting en -hantering; logistiese doeltreffendheid; finansiële beheer / bestuursmaatreëls en beplanningsprosesse. In hoofsaak kom dit daarop neer dat die Inspekteur-generaal SAW uitsluitlik optree as die Hoof van die SuidAfrikaanse Weermag se instrument om te kontroleer hoe doeltreffend die Weermag se administrasie funksioneer sodat regstellings - indien en waar nodig - gedoen kan word. In hierdie verband dien gemeld te word dat die Inspekteurgeneraal SAW geen uitvoerende gesag beklee nie maar sy take en funksies suiwer vir en namens die Hoof van die Suid-Afrikaanse Weermag verrig.

In die uitvoering van sy take en funksies moet die Inspekteur-generaal SAW spesiale aandag aan die effektiewe aanwending van mannekrag skenk. Een kardinale faset van die Inspekteurgeneraal SAW se taak is gesetel in die hantering van voorstelle en/of kritiek vanaf interne bronne. In hierdie verband moet daarop gewys word dat die Inspekteur-generaal SAW slegs aandag gee aan voorgelegde aangeleenthede wat regstreeks op weermagsadministrasie betrekking het (vide verwysing 26).

Sekere konsepregulasies rakende die aanstelling, pligte en status van die onderskeie Inspekteurs-generaal is op 14 Junie 1982 aan die vier weermagsdeelhoofde en ander belanghebbende instansies vir kommentaar en wysigings voorgelê. Hierdie voorlegging is opgeneem in Konsepwysiging van AR -11: Organisasie en Beheer. ${ }^{28}$

\section{Slotbeskouing}

In die voorafgaande oorsig is die rol van die Inspekteur-generaal in die geskiedenis van die Suid-Afrikaanse Weermag kortliks toegelig. Soos dit duidelik uit hierdie oorsig blyk, verteenwoordig dit haas nie ' $n$ deurlopende, volgehoue kroniek nie, dog kan met ' $n$ enkele opmerking in dié opsig volstaan word, $\mathrm{nl}$ dat die behoefte aan 'n militêre inspektoraat van tyd tot tyd opgeduik het. Soos die Unieverdedigingsmag algaande gegroei en ontwikkel het, het die noodsaak aan 'n stelsel waardeur aspekte van doeltreffendheid en slagvaardigheid normatief beoordeel kon word, dienooreenkomstig toegeneem. Reeds in die vroeë geskiedenis van die Suid-Afrikaanse verdedigingsorganisasie - toe dit as 't ware nog in sy kinderskoene gestaan het - was die probleem van 'inspeksie ' $n$ kilometer wyd en 'n sentimeter diep' reeds teenwoordig. Dit het die uitvoering van die Inspekteur-generaal se funksies op ' $n$ gesentraliseerde grondslag en oor ' $n$ wye spektrum in 'n groeiende militêre bestel uiters bemoeilik. Die daarstelling van afsonderlike inspektorate vir die onderskeie weermagsdele sedert 1970 het verseker dat die Inspekteurgeneraal SAW sy eie taak en funksies op ' $n$ rasionele grondslag kan verrig veral ten opsigte van sake van gemeenskaplike belang.

In hierdie opsig is hoofsaaklik aandag gegee aan die historiese rol van die Inspekteur-generaal wat die verdedigingsorganisasie in die geheel bedien het. Die instelling van Inspekteursgeneraal vir die onderskeie weermagsdele (die SA Leër, SA Lugmag, SA Vloot en SA Geneeskundige Diens) is slegs kortliks vermeld.

Ten slotte kan weer eens gewys word op die semantiese veranderinge waaraan die begrip Inspekteur-generaal onderhewig was. Hierdie waarneming moet egter gesien word teen die agtergrond van veranderde en veranderende omstandighede wat uiteraard op 'n evolusionêre wyse die rol en funksies van die Inspekteurgeneraal in ' $n$ wisselende organisatoriese raamwerk beïnvloed het.

"Kmat C.J. Nöthling, MA, is verbonde aan die Militêre Informasieburo van die SAW.

\section{Verwysings}

1. "Inspekteur-generaal, SAW: baanbrekersbenadering", Paratus Vol 32 No 12. Desember 1981, p 49

2. Unie van Suid-Afrika: Departement van Verdediging; Jaarverslagen voor 't jaar eindigende 30 Junie 1913, Kaapstad 1913, p 44. Brig genl Lukin het op 1 Julie 1912 diens aanvaar as Inspekteur-generaal, Staande Mag, ofskoon dié deel van die Unieverdedigingsmag eers op 1 April 1913 tot stand gekom het. Genl maj sir Lukin, wat in Januarie 1919 uitgetree het, is in 1925 oorlede.

3. "The Role of the Inspector General", Commanders Call (DA PAM 360 814), VSA 1973, p 47

4. The Oxford English Dictionary, Vol V (H-K), Oxford 1970, p 344.

5. DUNLOP, J.K., The Development of the British Army 1899 - 1914 , Methuen, Londen 1938, p 208

6. ARNOLD-FORSTER, H.O., The Army in 1906, John Murray, Londen 1906, p 482

7. HANNAH, W.H., Bobs - Kipling's General, Leo Cooper, Londen 1972, p 231.

8. JONKER, E., Ontstaan en ontwikkeling van die Transvaalse Verdedigingsmag 1900 - 1912, Magisterverhandeling, Universiteit van Pretoria 1971, p 114

9. Ibid, p 124.

10. Ibid, p 134

11. SAW Argief: AG $367 / 27$ (AG 1, Houer 882)

12. Unie van Suid-Afrika: "Verslag van de Inspekteur-Generaal, Staande Macht", uit: Jaarverslagen - Departement van Verdediging, Uitvoerende Bevelvoeringen voor 't jaar eindigende 30 Junie 1913 (Deel 2), Kaapstad 13 Augustus 1913, p 44

13. Ibid, p 45 
14. As bevelvoerder van ' $n$ Suid-Afrikaanse troepemag neem hy Ramansdrift (SWA) op 24 September 1914 in besit. Hierna voer hy bevel oor 'n berede kolonne in die Noordelike Mag van generaal Louis Botha. Ná generaal Botha se terugkeer na die Unie word hy aangestel as Bevelvoerende Generaal van die Uniemagte in SWA en in Augustus 1915 word hy Bevelvoerder SA Brigade in Egipte en Frankryk. Hy voer die SuidAfrikaanse kontingent aan tydens die slag van Delvillebos en word kort hierna tot generaal-majoor bevorder.

15. SAW Argief: AG (1) 66/34533 (G.0. 661).

16. "Die Militêre Inspektoraat", Kommando Vol 10 № 3, Maart 1959, 027. Volgens hierdie bedeling sou kol J.H. Robbertze (SM, DSO) beheer uitoefen oor aspekte rakende militêre opleiding (tegniese en vakopleiding uitgesluit). In latere jare het hy etlike belangrike poste beklee, onder meer dié van Adjunk-hoof van die Verdedigingstaf (Beplanning en Operasies) met die rang generaal-majoor. Onder die ander lede van die Inspektoraat was maj L.H. Groenewald, wat later as Direkteur-generaal Bestuurstelsels beheer oor die Verdedigingsinspektoraat uitgeoefen het. Die beampte wat as skakeloffisier tussen die militêre en burgerlike afdelings van die Departement van Verdediging aangewys is, was mnr C.W.C. van Heerden wat vantevore in die Algemene Afdeling van die Verdedigingsekretariaat gedien het.

17. Republiek van Suid-Afrika: Oorsig oor Verdediging en Krygstuigproduksie: Tydperk 1960 tot 1970, Verdedigingshoofkwartier, Pretoria April 1971, p 23.

18. Ibid, p 18

19. Ibid, $\mathrm{p} 22$. Die afdeling van die Direkteur-generaal Bestuurstelsels het op 1 Junie 1970 tot stand gekom.

20. "Promotions of Senior Officers", Kommando Vol 22 No 7, Julie 1970, p 79.

21. GROENEWALD, L.H., "Die verdedigingsinspektoraat", Kommando Vol 22 No 12, Desember 1970, pp 24-25.

22. Ibid, $p 69$

23. "Promotions of Senior Officers", $p 79$.

24. "Change of Guards", Paratus Vol 24 No 8, Augustus 1973, p 47. Lt genl Louw het vroeër in sy loopbaan bekendheid verwerf as stigter van SuidAfrika se eerste valskermbatalion. In Desember 1967 is hy op die ouderdom van 47 jaar tot luitenant-generaal bevorder en as Hoof van die Leër aangestel. Ná sy uittrede in 1975 het hy hom in Verwoerdburg gevestig waar hy in Julie 1980 skielik oorlede is.

25. SAW Argief. Volgens die voorgestelde konsep sou die Weermagsinspektoraat se doel wees om die slaggereedheid van die Suid-Afrikaanse Weermag te bepaal terwyl die inspektorate die slaggereedheid van hul onderskeie weermagsdele moes evalueer. Die voorgestelde stere van optrede vir die Weermagsinspektoraat sou onder meer betrekking hê op die interne sekerheidsmagte en die konvensionele magte, organisatoriese aspekte van die Suid-Afrikaanse Weermag se bevel- en beheerstruktuur met die $00 \mathrm{~g}$ op krygsverrigtinge en laastens, sekere ouditfunksies. Wat die weermagsdele se inspektorate betref, is aanbeveel dat hul funksies hoofsaaklik betrekking sou hê op die evaluering van operasies, logistiese ondersteuning en die toereikendheid en ekonomiese aanwending van hulpbronne. In die voorgestelde inspektorate is onder meer voorsiening gemaak vir die pos Direkteur van Inspeksie wat verantwoordelik sou wees vir die beplanning, beheer en monitering van inspeksiestelsels en veiligheidsprogramme. Op die volgende vlak is verskeie Inspekteurs- en Assistent-inspekteursposte in die vooruitsig gestel. Die aanbevelings van hierdie verslag was eintlik van groter betekenis sover dit die onderskeie weermagsdele betref; onderwyl die uitbouing van dié inspektorate grotendeels hierdeur beïnvloed is, kon 'n Weermagsinspektoraat (en die pos Inspekteur-generaal) eers ná verdere ondersoek vier jaar later geskep word.

26. SAW Argief. Wat sy taak en funksies betref, is die Inspekteur-generaal SAW in ' $n$ mate beïnvloed deur die Amerikaanse konsep van die sewentigerjare. In hierdie opsig kan gewys word op die voorligting soos vervat in Statement of Lieutenant General John P. Fiynn, the Inspector General, United States Air Force, before a Subcommittee on Military Personnel, 26 July 1977. Die primêre aspek wat in dié dokument belig is, nl die daarstelling en bedryt van ' $n$ "complaint systern", vorm deel van die Inspekteur-generaal SAW se funksies howel dit in die geval van die Suid-Afrikaanse Weermag uitsluitlik slaan op administratiewe aangeleenthede. Bykomende Amerikaanse bronne wat geraadpleeg is, sluit in Public Law 95 - 452: 95th Congress waardeur die daarstelling van Inspekteurs-generaal vir die Amerikaanse Departement van Verdediging en ander staatsdepartemente wetlik beslag gekry het; ' $n$ tydskrifartikel getiteld "Today's IG: the Eyes and Ears of the Army" deur It genl Richard G. Trefry wat in Army van Oktober 1979 verskyn het.

27. Genl maj Viljoen, wat in 1946 by die Staande Mag aangesluit het, het voor sy aanstelling as Inspekteur-generaal verskillende beiangrike poste beklee, onder meer dié van Bevelvoerder Kommandement Suid-Kaapland en Projekleier Lembus. Ná sy aanstelling as Inspekteur-generaal SAW, het hy voortgegaan om namens Hoof van die Suid-Afrikaanse Weermag Projek Lembus en ook Projek Horison te bestuur.

28. Hierdie konsepwysiging bepaal onder meer dat inspekteurs-generaal moet dien op die persoonlike staf van die Hoof van die Suid-Afrikaanse Weermag (die Inspekteur-generaal SAW) en die hoofde van die weermagsdele. Die toepaslike rang van posbekleërs, wat lede van die Staande Mag moet wees, is brigadier/kommodoor of hoër en die voorgeskrewe maksimum dienstydperk is vier jaar. Verder word bepaal dat alle inspekteurs-generaal, wanneer hulle daartoe geias word, ondersoek moet instel na en verslag doen oor die paraatheid van die hoofkwartiere, formasies en eenhede in 'n betrokke weermagsdeel. 